\title{
A Botanical Gardening Facility as a Method of Reclamation and Integration of Devastated Territories (Based on the Example of the Eden Project)
}

\author{
Olga Belousova, Tatiana Medvedeva, Zoia Aksenova* \\ St. Petersburg State University of Architecture and Civil Engineering, Saint Petersburg, Russian Federation
}

Received April 16, 2021; Revised June 8, 2021; Accepted July 19, 2021

\section{Cite This Paper in the following Citation Styles}

(a): [1] Olga Belousova, Tatiana Medvedeva, Zoia Aksenova, "A Botanical Gardening Facility as a Method of Reclamation and Integration of Devastated Territories (Based on the Example of the Eden Project)," Civil Engineering and Architecture, Vol. 9, No. 5, pp. 1309 - 1317, 2021. DOI: 10.13189/cea.2021.090504.

(b): Olga Belousova, Tatiana Medvedeva, Zoia Aksenova (2021). A Botanical Gardening Facility as a Method of Reclamation and Integration of Devastated Territories (Based on the Example of the Eden Project). Civil Engineering and Architecture, 9(5), 1309 - 1317. DOI: 10.13189/cea.2021.090504.

Copyright $\odot 2021$ by authors, all rights reserved. Authors agree that this article remains permanently open access under the terms of the Creative Commons Attribution License 4.0 International License

\begin{abstract}
The development of industrial production, in many countries, has led to the formation of large damaged urbanized industrial areas in the course of their active use. These are areas of former quarries, mines, landfills, and other places of industrial use. The issue of their restoration and further use is relevant both for European countries and for Russia. Botanical gardening in European countries, primarily in England, has become a national feature and is used in both traditional and innovative facilities. In Russia, it is believed that botanical gardening facilities require serious financial costs since special conditions must be created to maintain exotic plants. However, the question arises whether such objects will make a profit. The purpose of this article is to analyze the Eden Botanical Garden (the Eden Project) in Cornwall (England). The Eden Project was created on the territory of the former quarry and the adjacent territory. The analysis carried out in this article takes into account both environmental and activity-based approaches, as well as the historical and cultural method, which makes it possible to determine the general cultural significance of botanical gardening facilities. The study of this project showed the possibility of reclamation of the devastated territory by creating an innovative botanical gardening facility with a variety of functional uses. This project demonstrates the possibility of creating a self-sufficient, architecturally attractive, energy-efficient, and economically viable botanical gardening facility, which can be useful in the process of generating ideas for
\end{abstract}

creating a comprehensive methodology for transforming anthropogenic landscapes in Russia.

Keywords Botanical Gardening Facilities, Devastated Territory, Quarry, Botanical Garden, Urban Planning Aspects, Reclamation, Energy Efficiency

\section{Introduction}

In contrast to the disorderly use of land in the past, much attention is now paid to territory planning [1]. This approach assumes the optimal use of land to best meet the needs of the population $[1,2]$. The urgency of the problem lies in the fact that the optimal use of urban areas is impossible if large in area, not rehabilitated, devastated land plots remain in the settlement. It is believed that botanical gardening facilities (BGFs) require serious financial costs since special conditions must be created to maintain exotic plants. There is an opinion that such facilities do not bring profit [3]. We propose to consider the Eden Project created on the territory of the former quarry of Cornwall.

The purpose of this article is a comprehensive analysis of a successful project since the rehabilitation of devastated lands on the territory of the city and its 
outskirts allows them to be integrated into the urban environment, to use the opportunities of these lands as efficiently as possible, ensuring the development of their socio-economic potential. The study of the characteristics and classification of devastated lands are of great importance for the rational planning of urban space [4].

\subsection{Literature Review}

The material for this study was cartographic, iconographic, statistical materials, and electronic resources related to this object, as well as the works of $\mathrm{N}$. V. Konshina [5], F. D. Mubarakshina [6], T. A. Medvedeva in the field of ecology [7], works by V. A. Nefedov [8], S. P. Zavarikhin [3], V. S. Teodoronsky, E. D. Sabo, V. A. Frolova, G. Grub [9] in the field of landscape architecture and urban planning, works by N. A. Makeev [10], and reviews by I. Allen [11].

The article by NV Konshina examines the development of proposals considered in design, leading to an increase in the level and preservation of health, the general quality of life, and mutual harmonious interpenetration and interaction of the artificial and natural environment [5].

Based on the issues of modern urban planning practice, S.P. Zavarikhin, V.A. Nefedov, and T.A. Slavina describe characteristic manifestations of insufficient ecological efficiency of the implemented projects [3]. The method of structuring the re-naturalization of the transformed territories is described and factors that can be considered in the implementation of urban ecological reconstruction are presented.

Psychological aspects of the perception of the surrounding urban environment, influencing the mental comfort of a resident today, are considered in the article by F.D. Mubarakshina [6]. The level of environmental quality is assessed: the necessary and sufficient level of urban greening, favorable ecological state, and the preservation of the connection between man and nature.

The article by N.A. Makeeva provides an overview of modern methods of accelerated reclamation of lands disturbed by coal mining both in Russia and abroad [10] and describes traditional and innovative methods of biological remediation.

The issues of creating objects of landscape architecture, landscaping of the territory of objects related to the organization of construction of engineering structures, the design of the road network, regulation of the water regime in the territories of objects, the nomenclature, structures, and construction materials are discussed in detail in the work by V.S. Teodoronsky, E.D. Sabo, and V. A. Frolova [9].

The causes of the emergence of a depressive environment and scenarios of interaction between participants in the urban planning process are described in the articles by T.A. Medvedeva [7].

\section{Materials and Methods}

For this study, we chose an environmental (urban planning) and activity-based (functional) approach. To identify the general cultural significance of BGFs, we used the historical and cultural method.

Additionally, the research work was carried out by the following methods:

- the problem/logic-based method of interconnected study of archival, literary, cartographic materials, as well as materials of field surveys;

- the formal/stylistic method that allows tracing in detail the genesis of various formal concepts.

In this paper, the analysis of the territory and the architectural BGF located on it takes into account the following aspects: architectural and urban planning, environmental, innovative and scientific and technical, as well as socio-economic ones. The combined use of these methods allows creating a stereoscopic view of the research method.

\subsection{Territory Analysis}

The Eden Project has contributed to the development of tourism in Cornwell. This county, sometimes called the Cornwall Peninsula, is considered one of the brightest scenic spots in England. Cornwall is distinguished by a temperate climate, excellent natural conditions, distinctive Celtic culture, and the rich history of the region. It is the location of the westernmost point of Great Britain, Cape Lands End, and the southernmost point, Cape Lizard. A feature of the county is that there is not a single large city on the territory of Cornwall. The capital of the county is Truro. The population is 515 thousand people. The area is $3,563 \mathrm{~km}^{2}[12,13]$.

Cornwall is located in the southwestern part of England, washed by the English Channel on one side and the waters of the Atlantic Ocean on the other, which makes its coast so attractive for numerous tourists. Besides that, Cornwall has a huge number of beaches, some of which have priceless landscapes. There are places for recreation with great potential. This potential can be fully developed with the correct functional organization of the territories. However, there are large areas of territories where, as a result of human industrial activity, one can observe "characteristic manifestations of the problem of insufficient environmental efficiency of the implemented projects" [8].

\subsection{Factors Influencing the Tourist Attractioveness of Cornwall}

Cornwall's tourist attractiveness is shaped by its many historical, cultural, and natural resources. Cornwall is one of the most picturesque places in all the UK. The combination of such factors as the quiet measured life of 
the rural hinterland and the presence of sandy beaches have turned the peninsula into a popular place for tourists and vacationers. The rich historical heritage of Cornwall includes: archaeological sites; cult and civil architecture; monuments of landscape architecture; small and large historical cities; rural settlements; objects of ethnography, folk crafts and crafts, centers of applied arts. A very important component of tourist attraction in modern conditions is the quality of the environment. Natural tourism resources are important elements of the tourist attraction of the area.

Cornwall has a temperate maritime climate, the mildest and sunniest in the UK, as a result of its relatively southerly position and the influence of the Gulf Stream. Average annual temperatures range from $11.6^{\circ} \mathrm{C}$ to $9.8^{\circ} \mathrm{C}$ in the central highlands. Winters are mild, and frosts are extremely rare. Summers are not as warm as in other parts of southern England. Moist air from the southwest is responsible for higher rainfall compared to the regions of England to the east (1051 to $1290 \mathrm{~mm}$ ), but not as high as in the more northern regions of the west coast $[12,14]$ The region has mild windy winters and sunny cool summers. Since the 19th century, botanists have appreciated the climatic features of this area and began to plant there exotic plants that are not found throughout England.

Cornwall attracted tourists not with its historical landmarks, but mainly with the beauty of nature and the mildness of the climate. Therefore, the transformation of disturbed landscapes is one of the most promising areas for the development of this territory. Cornwall is not so rich in attractions, although the bulk of the income depends on the tourism industry. In this regard, the design and construction of a unique tourist facility with a museum and exhibition function is becoming relevant. Besides, the multifunctional complex also develops the local infrastructure of the system of research and educational institutions. Cornwall has two institutions of higher education, the Camborne Mining Institute and Falmouth College of Art, as well as 12 colleges and 31 high schools [13].

The territory of Eden Project, with an area of 25 hectares, is located at a distance of 1.5 kilometers from the city of Saint Austell (Figure 1), 5 kilometers from the sea coast and the English Channel. St. Austell is located 530 kilometers west of London, the capital of Great Britain. The population of the city amounts to about 23 thousand people $[13,14]$.

Cornwall Airport Newquay is the main commercial airport in Cornwall, located 7 kilometers northeast of the city of Newquay on the northern coast of the peninsula. The distance from Eden Project to the airport is about 29 kilometers [14].

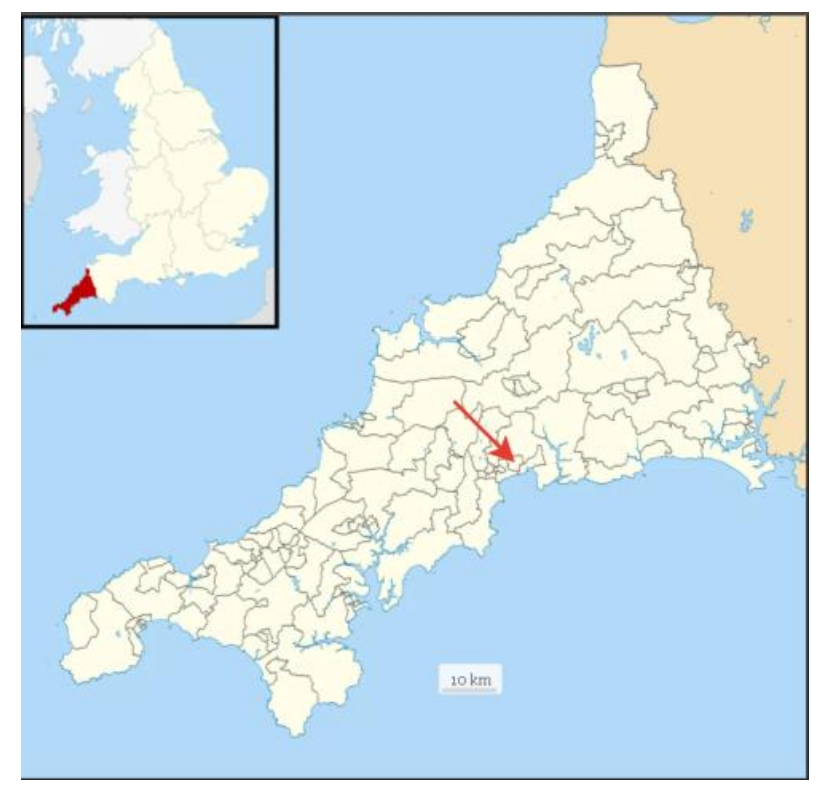

Figure 1. Territorial location of the Eden Project

\subsection{Types of Devastated Territories}

The construction of artificial relief, as the main method of revitalizing depressed areas for their prospective urban planning, poses new challenges for the designers. The rapid development of cities, together with the intensification of industrialization processes, is accompanied by the growth of several problems, such as environmental degradation, imbalance in tourism development between regions, great competition, and a change in priorities in the tourism industry. The interest of tourists is gradually shifting from traditional tourism to a new type, such as natural tourism or eco-tourism. Solving the problems of returning disturbed lands to economic circulation requires innovative approaches to the urban planning process $[2,10,15]$.

This study is carried out to identify a strategy for integrating depressed areas of former quarries, ensuring sustainable development of adjacent territories.

The landforms occurring in nature are almost always natural and beautiful. However, the results of anthropogenic impact are beautiful only if they are thought out by specialists. These forms have to be planned and cannot emerge from spontaneous activity. All kinds of sports parks, children's amusement parks, dog parks, botanical and zoological gardens, industrial landscape zones are recommended for placement in devastated territories $[5,6,9]$. 
The following types of devastated territories can be identified:

Territories of melted permafrost, affected by natural disasters, affected by man-made disasters and hostilities, territories with changed relief, areas affected by unauthorized storage of waste.

This article examines a quarry as one of the types of territory affected by industrial activity. Abandoned quarries for the extraction of minerals lead to such phenomena as soil erosion, weathering, dusty tornadoes, lack of a fertile layer, and other adverse environmental consequences.

\subsection{Sites of Special Scientific Interest (SSSI)}

Agricultural land accounts for $73.64 \%$ of the county territory, about $7.5 \%$ is covered by forests. There are 167 SSSIs registered in the county. SSSI is a term for a protected natural site in the UK [13].

Among these monuments (SSSIs in the territory of Cornwall), more than one hundred hectares are occupied by devastated areas of former quarries. Among them, there are many objects of scientific observation worthy of a museum display. Here it is possible to preserve, study and exhibit material evidence of the development of technical progress by various means based on both archaeological monuments and the latest methods of museum demonstration [15]. These territories are an example of a framework for the development of any of the promising areas, for example, tourism infrastructure $[7,9,15]$.

In connection with the consideration of the topic of transforming devastated territories, Table 1 presented below reflects only a part of the SSSIs in England, namely quarries and mines [14].

Table 1. Quarries and mines in Cornwall

\begin{tabular}{|c|c|c|c|c|}
\hline $\begin{array}{c}\text { Item } \\
\text { No. }\end{array}$ & Year & Name & Original name & Area (ha) \\
\hline 1 & \multirow{2}{*}{1951} & St Agnes Beacon Pits & St Agnes Beacon Pits & 7.9 \\
\hline 2 & & Tregargus Quarries & Tregargus Quarries & 1.8 \\
\hline 3 & 1953 & Stourscombe Quarry & Stourscombe Quarry & 0.5 \\
\hline 4 & 1962 & St Erth Sand Pits & St Erth Sand Pits & 3.9 \\
\hline 5 & 1973 & Mulberry Downs Quarry & Mulberry Downs Quarry & 3.2 \\
\hline 6 & 1985 & Viverdon Quarry & Viverdon Quarry & 0.4 \\
\hline 7 & \multirow{2}{*}{1988} & Polyne Quarry & Polyne Quarry & 0.1 \\
\hline 8 & & Wheal Gorland & Wheal Gorland & 0.6 \\
\hline 9 & \multirow{3}{*}{1990} & Yeolmbridge Quarry & Yeolmbridge Quarry & 0.7 \\
\hline 10 & & Wheal Alfred & Wheal Alfred & 1.1 \\
\hline 11 & & Wheal Martyn & Wheal Martyn & 0.1 \\
\hline 12 & \multirow{3}{*}{1993} & Penberthy Croft Mine & Penberthy Croft Mine & 2.3 \\
\hline 13 & & Luxulyan Quarry & Luxulyan Quarry & 49.9 \\
\hline 14 & & Wheal Penrose & Wheal Penrose & 0.9 \\
\hline 15 & 1994 & Polyphant & Polyphant & 3.4 \\
\hline 16 & 1996 & South Terras Mine & South Terras Mine & 0.6 \\
\hline 17 & 1997 & Penlee Quarry & Penlee Quarry & 25.8 \\
\hline 18 & 2000 & St Austell Clay Pits & St Austell Clay Pits & 0.6 \\
\hline
\end{tabular}

Source: compiled by the authors 


\subsection{Architectural and Constructive Solution for the Greenhouse Complex}

There are two large-scale greenhouses on the territory of this complex, and each of them consists of several domes. The area occupied by these buildings is many times larger than the area of the largest historical greenhouses and is 22,000 square meters. This is the largest modern greenhouse complex built in a short time, in just 2.5 years by the project of the architect Nicholas Grimshaw [16,17].

The complex landscape of the area influenced the placement of objects on the site, determined their size and significance in the complex. The bionic principle of greenhouses allowed them to organically fit into the existing environment and contrast with it at the same time (Figure 2).

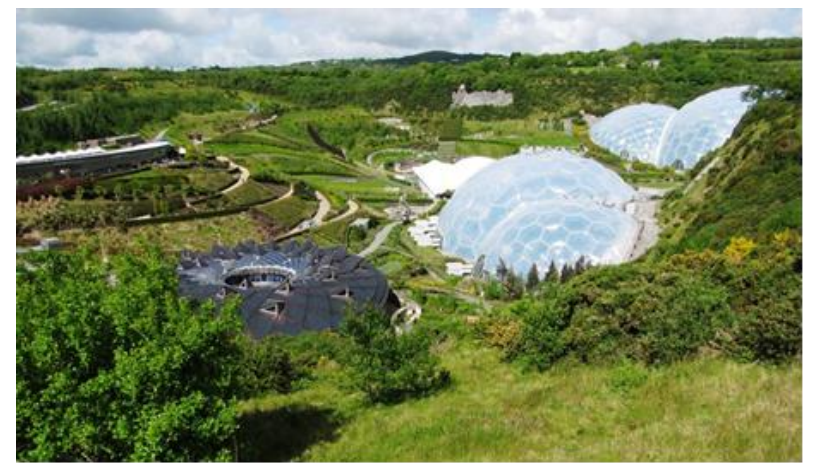

Figure 2. A view of the complex from the north-eastern slope. Source: https://revitalization.org/article/get-masters-sustainability-restorative-ede n-project-cornwall-uk/

The organization of the interior space forced the architect to turn to the already well-known geodesic dome design created in the 1940s by Richard Fuller. Before the implementation of this futuristic project, geodesic domes were used in exhibition pavilions, hangars, greenhouses. However, those were single, detached structures.

This object of botanical architecture is an example of the organization of a modern, balanced, compositionally verified, large-scale space both for the surrounding territory and for humans, since its geometric characteristics allow free placement of tall plants and form an environment close to the natural habitat of different plant species, both from the point in terms of climate and terrain $[2,18]$.

The large greenhouse (Tropical Biome) covers an area of 1.5 hectares, the maximum height of the dome is 50 meters, and its diameter is 110 meters (Figure 3). The small greenhouse (Mediterranean Biome) with an area of 0.6 hectares has a height of 35 meters and a diameter of 65 meters. The total length of the greenhouses is 375 meters; they are located in the northern part of the complex and are compositionally completing objects. Between themselves, both greenhouses are connected by a covered walkway, where the public catering facility is located [11, 17-19].
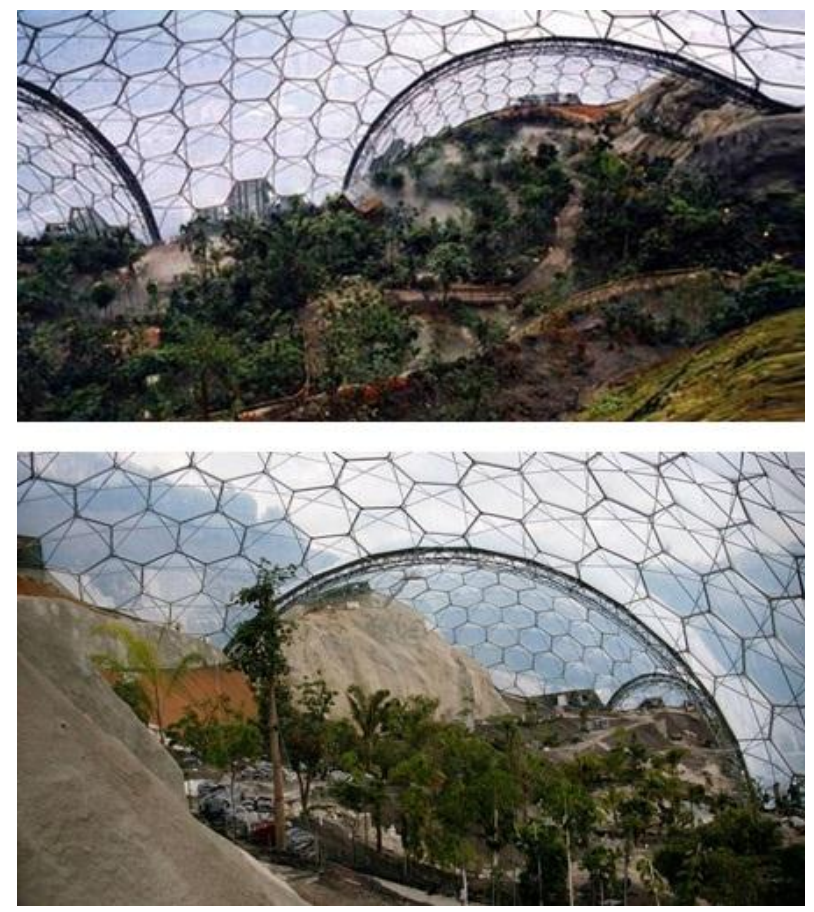

Figure 3. Internal volume of the Tropical Biome in the Eden Project. Source:

https://inhabitat.com/eden-project-giant-bubble-biomes-are-worlds-large st-greenhouse
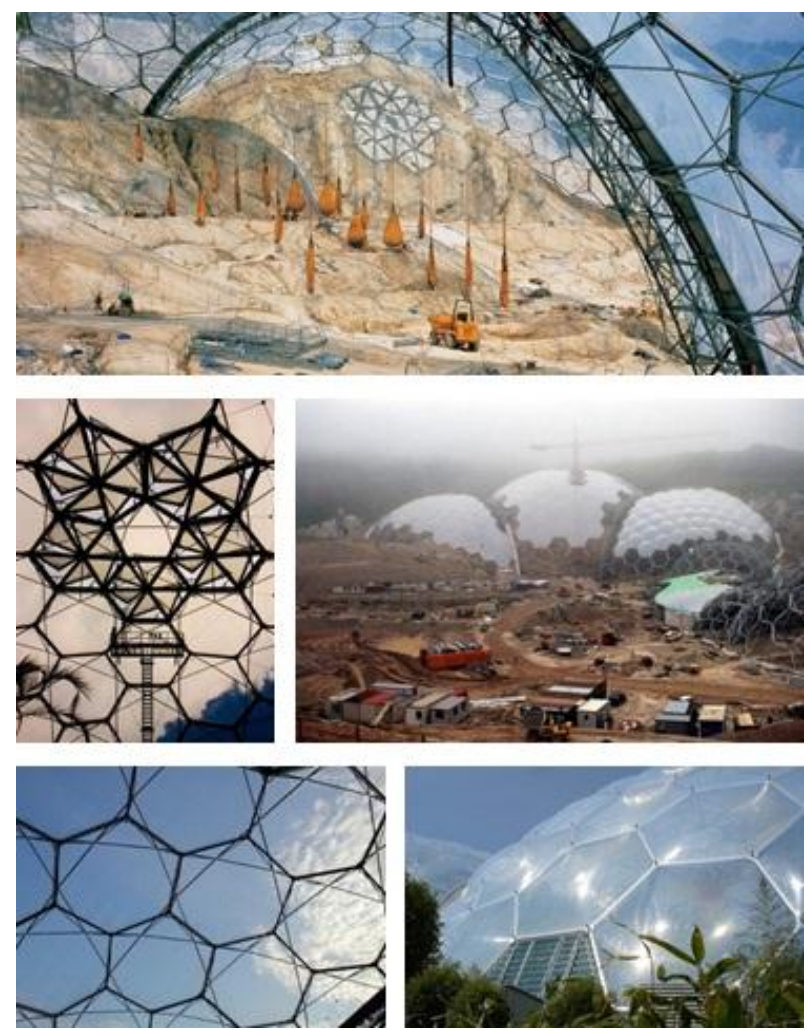

Figure 4. Engineering and design features of the greenhouse. Source: https://www.gettyimages.com/detail/news-photo/interior-of-the-humid-tr opic-biome-at-the-eden-project-near-news-photo/830566428 
A honeycomb, mostly hexagonal metal structure made of steel elements of small diameter, filled in the form of pneumatic lenses, in which a very durable light-conducting plastic is used, distinguishes this object from many similar ones (Figure 4).

The honeycomb steel component of the dome is perceived from the inside as a light mesh. It was this design that facilitated the use not of glass, traditionally used in greenhouses, but of high-tech multilayer plastic. Heat losses in the structure are compensated for by an air gap that is provided between the layers of pneumatic lenses. The volume of each lens is adjusted by pumping air. The greenhouses are fully computerized. Here, not only innovative technologies have been applied in terms of heat conservation, but also water supply and waste disposal. The facility uses a closed water supply system, carried out by collecting atmospheric precipitation and draining groundwater, which ensures the normal functioning of all facilities located at the lower level (pit depth 60 meters from ground level). The facility also has its own small but efficient waste processing plant located on the northern slope. A feature of this facility is the use of fresh locally produced vegetables and fruit to provide a public catering facility included in the greenhouse complex. All the plants placed in the complex are the result of the collective work of botanists from all over the world, as they were grown and brought from the greenhouses of other botanical gardens [11] The main purpose of this complex is the ecological education of both children and adults, the organization of concerts, exhibitions, workshops, etc. [3,11,17].

These greenhouses were not the first ones to use this constructive solution, but they became the only ones of their kind since before them greenhouse complexes had been built with more narrowly focused objectives in mind. This project made it possible to transfer the BGF from the status of the environment-forming object to the status of city-forming one, which, due to its multifunctional use, was able to replace large industrial production, radically change the ecological situation in the adjacent territory and create a new tourist attractive aesthetic environment, as evidenced by the statistical data presented in Table 2 [20].

\section{Results and Discussion}

A comprehensive analysis of the transformation of the territory of the former quarry using the example of Eden Project in Cornwall, UK, allows us to identify the characteristic results obtained from the implementation of this project. The results are presented in Table 3, taking into account the following aspects: urban planning, architectural planning, environmental, innovative, economic, and social.

Botanical gardening of European countries, which began its development in the 14th century, acquired in England the status of not only national culture but also a national policy [2]. The beginning of the 21 st century has defined a new stage in its development, which is evidenced by the implementation of such an unusual project, demonstrating an integrated approach to solving the problem of reviving the devastated territory [21]. This project became the first example of the application of modern innovative solutions and served as an impetus for the further development of interior BGFs. Various principles of shaping and continuity of architectural styles have determined the diversity of modern forms in the objects of interior botanical gardening in the area under consideration. Non-standard solutions have found application in an equally large project implemented in Singapore in 2012 during the creation of Gardens by the Bay in reclaimed areas. This approach demonstrates the historical continuity, the desire to preserve the national tradition in the botanical sphere, the preservation of objects of special scientific value, and their integration into the modern architectural environment.

In some works considering the problems of devastated territories, attention is mainly paid to the specifics of morphogenetic types [1], ecological problems of territories [22], economic and legal problems of devastated territories in the Russian Federation, measures to optimize these territories, the prospects for their implementation and associated risks [23].

This study is a necessary addition to the study of the urban fabric of the city in the context of damaged urbanized industrial areas and their integration into the socio-cultural context of the urban environment. A strategy was identified for the integration of depressed areas of former quarries, which ensures the sustainable development of adjacent territories in conjunction with interior BGFs.

Table 2. Statistical data

\begin{tabular}{|c|c|c|c|c|c|}
\hline country/facility & BGF area & $\begin{array}{c}\text { costs } \\
\text { for construction }\end{array}$ & revenue per year & $\begin{array}{c}\text { planned number of } \\
\text { visitors }\end{array}$ & $\begin{array}{c}\text { real number of } \\
\text { visitors }\end{array}$ \\
\hline $\begin{array}{c}\text { Great Britain } \\
\text { the Eden Project }\end{array}$ & 25 ha & 133 mln pounds & 730 mln pounds & $750-1,000$ visitors & $\begin{array}{c}\geq 2,000 \text { visitors per } \\
\text { year }\end{array}$ \\
\hline
\end{tabular}

Source: compiled by the authors 
Table 3. The characteristic results obtained from the implementation of the project

\begin{tabular}{|c|c|c|}
\hline $\begin{array}{l}\text { Item } \\
\text { No. }\end{array}$ & Aspects & Results obtained from the implementation of the project \\
\hline 1 & $\begin{array}{c}\text { Urban } \\
\text { planning }\end{array}$ & $\begin{array}{l}\text { 1. The integration of the devastated territory of the former quarry into the planning structure has led to a } \\
\text { change in the urban status of the county territory and an increase in the quality of life; } \\
\text { 2. The existing transport infrastructure has been used and expanded; } \\
\text { 3. New connections have emerged with existing trade, sports and entertainment facilities, and catering } \\
\text { 4. The waste management and management infrastructure have been upgraded. }\end{array}$ \\
\hline 2 & $\begin{array}{l}\text { Architecture } \\
\text { and planning }\end{array}$ & $\begin{array}{l}\text { 5. The new aesthetics of the BGF has been created through the use of the latest construction technologies } \\
\text { and materials; } \\
\text { 6. The shape of the greenhouses and service facilities highlights the existing antagonism between the } \\
\text { "plant kingdom" and the human community; } \\
\text { 7. Correspondence of the scale of the BGF to the large scale of the transformed technogenic relief. }\end{array}$ \\
\hline 3 & Environmental & $\begin{array}{l}\text { 8. The construction of the facility prevented soil erosion, dust tornadoes, noise, and other adverse factors; } \\
\text { 9. The area of green and landscaped territory has increased; } \\
\text { 10. Environmental education has become the basis for the formation of collective values; } \\
\text { 11. The rational use of energy resources has become a declaration of the ecological approach. }\end{array}$ \\
\hline 4 & Innovative & $\begin{array}{l}\text { 12. The construction of the facility contributed to the transfer and consolidation of botanical knowledge; } \\
\text { 13. Testing and implementation of modern technologies in all areas of construction have been carried out. }\end{array}$ \\
\hline 5 & Economic & $\begin{array}{l}\text { 14. The design of the unique facility provided an influx of capital and increased the investment } \\
\text { attractiveness of the territory; } \\
\text { 15. The emergence of a new city-forming enterprise contributed to the creation of new jobs; } \\
\text { 16. There has been an increase in tourist activity; } \\
\text { 17. The BGF supports and develops the food infrastructure; } \\
\text { 18. The greenhouse complex is conceived as a priori cost-effective object. }\end{array}$ \\
\hline 6 & Social & $\begin{array}{l}\text { 19. Creating a qualitatively new psycho-emotional educational environment; } \\
\text { 20. This project has shown the economic viability of the BGFs; } \\
\text { 21. The specificity of the general plan of the Eden Project allowed it to become the hallmark of England, } \\
\text { focused on the perception from the air. }\end{array}$ \\
\hline
\end{tabular}

Source: compiled by the authors

A comprehensive analysis of the transformation of the former quarry using the example of Eden Project in Cornwall, UK, revealed the characteristic results obtained from the implementation of this project, taking into account the following aspects: urban planning, architectural planning, environmental, innovation, economic and social aspects. The theoretical and practical significance of the work is explained by the fact that the revealed regularities of the relationship between the architectural and urban planning characteristics of the interior buildings of botanical gardening of the classical orientation will supplement the corresponding sections of the theory of architecture and can be used in the study of architecture and urban planning of cities in Russia and the world.

\section{Conclusions}

The implementation of the reclamation project of the devastated territory has demonstrated the self-sufficiency, energy efficiency, and economic viability of the BGF. The analysis of this project showed both a way of preserving cultural heritage, through its development, the possibility of transforming the anthropogenic landscape, and the organization of a new approach in the development of the architecture of BGFs. We have demonstrated the influence of botanical gardening on the cultural and economic development of territories, as well as the education and spiritual development of citizens.

This work is aimed at involving professionals in various areas of design and can be useful in the process of generating ideas for creating a comprehensive methodology for transforming the anthropogenic landscape in Russia. The economic results demonstrated in the article obtained during the operation of this facility can help to attract the attention of potential investors in Russia to the BGFs, including historical ones, as to the category of a priori cost-efficient city-forming objects, with a scientific, educational, and cultural and educational function that can serve as a huge tourist attraction.

\section{Acknowledgements}

We express our gratitude for the comprehensive support and assistance in preparing the material to Professor, Doctor of Architecture, Head of the Department of 
Architectural and Urban Planning Heritage of St. Petersburg University of Architecture S.V. Sementsov, Professor, Doctor of Architecture A.G. Vaitens (Urban Planning Department of St. Petersburg Architectural and Construction University), and Candidate of Architecture O.I. Paryeva.

\section{REFERENCES}

[1] A. Y. Andreev. Analiz kharakteristik i klassifikatsiya devastirovannykh zemel g. Saratova [Analysis of characteristics and classification of devastated lands of Saratov], Izv. Sarat. un-ta. Nov. ser. Ser. Nauki o Zemle [Series: Earth science], Vol.17, No.1, 5-12, 2017. https://doi.org/10.18500/1819-7663-2017-17-1-5-12

[2] O. A. Belousova. K voprosu sushchestvovaniya obektov botanicheskogo sadovodstva v strukture razvivayushchegosya goroda [On the question of the existence of botanical gardening facilities in the structure of a developing city], Modern problems of history and theory of architecture. Collection of reports of the III scientific-practical conference, St. Petersburg, Russia, April 26, 2017, pp. 73-78.

[3] S. P. Zavarikhin, V. A. Nefedov, T. A. Slavina. Nekotorye osnovy teorii arkhitekturno-gradostroitelnykh preobrazovanii [Some foundations of the theory of architectural and urban planning transformations], Vestnik grazhdanskikh inzhenerov, Vol.6, No.59, 49-52, 2016.

[4] Z. Aksenova, O. Belousova. Classical Trends in the Architecture of Botanical Objects in Scandinavia, Civil Engineering and Architecture, Vol.8, No.4, 426-432, 2020. DOI: $10.13189 /$ cea.2020.080404.

[5] N. V. Konshina. Ekologicheski orientirovannaya sreda kak osnova dlya proektirovaniya sovremennykh zdanii [Eco-friendly environment as a basis for the design of modern buildings], Arkhitekton No.30, 2010, http://book.uraic.ru/project/conf/txt/005/archvuz30_pril/02 7/027.htm (access date 08.11.2019).

[6] F. D. Mubarakshina. K probleme sozdaniya zon ekologicheskogo komforta $\mathrm{v}$ usloviyakh uplotnennoi zastroiki megapolisa [On the problem of creating zones of ecological comfort in the conditions of dense urban development], Izvestiya KGASU, Vol.3, No.25, 28-32, 2013.

[7] T. A. Medvedeva. Prirodnye i iskusstvennye elementy v planirovochnoi strukture sportivnykh parkov [Natural and artificial elements in the planning structure of sports parks], Sbornik materialov konferentsii SPbGASU [A collection of papers presented at the SPbGASU conference], Vol.62, 181-184, 2009.

[8] V. A. Nefedov. Kachestvo gorodskoi sredy kak integriruyushchii faktor arkhitektury gradostroitelstva i dizaina [The quality of the urban environment as an integrating factor in the architecture of urban planning and design], Regionalnaya arkhitektura i stroitelstvo, No.1, 165-169, 2012.
[9] V. S. Teodoronskii, E. D. Sabo, V. A. Frolova. Stroitelstvo i ekspluatatsiya obektov landshaftnoi arkhitektury [Construction and operation of objects of landscape architecture], Izdatelskii tsentr Akademiya, Moscow, 2007.

[10] N. A. Makeeva, O. A. Neverova. Obzor metodov uskorennoi rekultivatsii narushennykh ugledobychei zemel [Review of methods for accelerated reclamation of areas damaged with coal mining], Vestnik KrasGAU, No.8, 77-86, 2016.

[11] N. Gromshou. Proekt Edem [The Eden project], Proekt $\begin{array}{llll}\text { klassika, No.4, Jul. } & 27,\end{array}$ http://www.projectclassica.ru/v_o/04_2002/04_v_01.htm (access date 08.11.2019).

[12] Angliya [England], Seriya Russkii gid - Poliglot [Series: the Russian guide - Polyglot], Ayaks-Press, Moscow, 2010, p. 108.

[13] Office for National Statistics. Population Estimates for UK, England and Wales, Scotland and Northern Ireland (English), 2020 , https://www.ons.gov.uk/peoplepopulationandcommunity/p opulationandmigration/populationestimates/datasets/popul ationestimatesforukenglandandwalesscotlandandnorthernir eland (access date 08.11.2019).

[14] D. Christopher. Angliya. Istoriya strany [Traveller's History of England], Eksmo, Moscow, 2007, https://libking.ru/books/sci-/sci-history/529978-daniel-krist ofer-angliya-istoriya-strany.html (access date 08.11.2019).

[15] M. A. Granstrem. K voprosu o sokhranenii i renovatsii istoricheskoi territorii izhorskikh zavodov [On the issue of preserving and renovating the historical territory of the Izhora factories], Arkhitekton: izvestiya vuzov, Vol.4, No.16, 7, 2006.

[16] E. Dolgova. Vozvrashchenie v Edem [A return to Eden], Nauka i Zhizn, No.6, 36-39, 2008.

[17] Oranzhereinyi kompleks Edem [The Eden greenhouse complex], AirRoof. Constructions \& Technology, http://airroof.ru/design-and-ideas/teplitsy (access date 08.11.2019).

[18] Proekt Edem v Velikobritanii [The Eden Project in Great Britain], STRANY MIRA ZOOM.EX, Feb. 17, 2013, http://www.zoomex.ru/chudesa-sveta/proekt-edem-v-velik obritanii (access date 08.11.2019).

[19] O. Frolova, "Proekt Edem - neveroyatnoe perevoploshchenie promyshlennogo karera" [The Eden project: an unbelievable transformation of an industrial quarry],

TravelAsk http://travelask.ru/blog/posts/9696-proekt-edem-neveroyat noe-perevoploschenie-promyshlennogo-kar (access date 08.11.2019).

[20] A. M. Platonov, "Proekt Edem botanicheskii sad novogo pokoleniya" [The Eden project: a botanical garden of the new generation], Proza.ru, Feb. 15, 2018, https://www.proza.ru/2018/02/15/1101 (access date 08.11.2019).

[21] I. Bulakh, I. Merylova. Sustainable Hospital Architecture Potential of Underground Spaces, Civil Engineering and Architecture, Vol.8, No.5, 1127-1135, 2020. DOI: 10.13189/cea.2020.080539. 
[22] O. B. Yarosh, V. G. Kobechinskaya. Podkhody k ustoichivomu razvitiyu devastirovannykh territorii [Approaches to the sustainable development of devastated territories], Biosfera-XXI veka: III vseukrainskaya konferentsiya molodykh uchenykh, aspirantov i studentov [Biosphere of the 21st century: the 3rd All-Ukrainian Conference of Young Scientists, Postgraduates and
Students], Sevastopol, Crimea, Ukraine, April 4-7, 2011, pp. $162-163$.

[23] E. Voskresenskaya, V. Snetkov, A. Tebryaev, Z. Askarov. Atypical real estate objects: legal regime and control system, MATEC Web of conferences, Vol.106, 08055, 2017. http://dx.doi.org/10.1051/matecconf/201710608055 